http://jmscr.igmpublication.org/home/

ISSN (e)-2347-176x ISSN (p) 2455-0450

crossref DOI: https://dx.doi.org/10.18535/jmscr/v7i9.02

Journal Of Medical Science And Clinical Research

\title{
A Study on Management and Outcome of Thoracolumbar Spinal Trauma with Neurological Deficit
}

\author{
Authors \\ Dr M.A Basit ${ }^{1}$, Dr Richa Sharma ${ }^{2 *}$ \\ ${ }^{1}$ Consultant Orthopedic Spine Surgeon, Mannnat Hospital Sundernagar H.P \\ ${ }^{2}$ Assistant Professor SLBS GMC Nerchowk H.P \\ *Corresponding Author \\ Dr Richa Sharma \\ Assistant Professor SLBS GMC Nerchowk H.P., India
}

\begin{abstract}
Thoracolumbar fractures have been treated conservatively in the past. This mode of treatment is accompanied with various complications. It is very laborious. Cost of therapy in terms of hospital stay and care by trained personnel is also very high. In our country, where there is an acute shortage of trained persons conservative management, more often ends up as benign neglect.

Methodology: This study was a prospective study of fixation with pedicle screw and fusion in traumatic unstable thoracolumbar spine. During the period 20 cases of traumatic thoracolumbar spine fractures were treated surgically with posterior decompression and fusion.

Results: In our study 55\% of the cases were of Grade A power, 25\% cases were Grade C power and 20\% of cases were of Grade B power on admission. Only 30\% patients had useful recovery (Grade D \& E) .Type A fractures and type $B$ fractures had incidence of $40 \%$ each. Fall from height was the most common cause. Conclusion: It was observed that posterior stabilization with pedicle screw was effective. And showed improvement in the neurological status.

It was much better in patients with incomplete cord Injury. Early mobilization and ambulation are the major advantages of this procedure. The results in our series of 20 cases have been encouraging. But there is need for more cases and longer follow-up.

Keywords: thoracolumbar fractures, management, complications, pedicle screws.
\end{abstract}

\section{Introduction}

Injuries to spine are dreaded problems. They cause infinite morbidity and disability to the patient. If not treated urgently \& rationally, patient may be confined to bed for the rest of his life ${ }^{[34]}$. Thoracolumbar spine is the most commonly injured part of the spine. In this era of increasing mechanization, automobiles and industrialization, there is sharp increase in physical trauma and spinal cord injuries. Incidence of traumatic spinal cord injury is estimated to be between $29-50$ million cases per year ${ }^{(2)}$. Motor vehicle accidents is the most common cause of traumatic spinal cord injury $(>45 \%)$, other causes include fall from height $(>25 \%)$ and gunshot injuries $(15 \%)$. The gender propensity is about $4: 1^{(6,7)}$.

It perhaps is the worst of all survivable trauma's in terms of psychological and socio-economic impact. Historically, thoracolumbar fractures have been treated with bed rest for a period of 8-12 
weeks $^{[35,36]}$. This mode of treatment is accompanied with complications in terms of hospital stay, bed occupancy and care by trained personnel $^{[34]}$. In a country like ours, where there is acute shortage of hospital facilities, conservative management ends up being a benign neglect. So there is an urgent need for exploring possibility of surgical stabilization, early mobilizations and rehabilitation of patients. Surgical treatment can be by anterior, posterior, lateral or anteroposterior approaches. As most spine surgeons are more experienced in posterior approach, it is a safe alternative. This study was conducted to ascertain the results of Pedicle screw fixation for operative treatment of thoracic and lumbar spine injuries with neurological deficit.

\section{Material and Methods}

20 cases of different age group and gender with fractures and fracture dislocation of thoracic and lumbar spine admitted in GMC Jammu from 2006to 2008 were studied .On arrival, the patient was assessed and stabilized in terms of airway, breathing and circulation. Immobilization was done on a hard board. Detailed history, thorough physical and neurological examination was carried out. Patient was started on Intravenous dose of methyl prednisolone as per National Spinal Cord Injury Study (NASCIS-III) recommendation. Radiological examination and MRI was performed to know the exact level of injury, extent of injury, kyphotic angle and loss of vertebral height. Chest physiotherapy, care of back, bowl and bladder was performed

\section{Exclusion Criteria}

- Pathological fractures

- Stable/unstable fractures without neurological deficit.

- Gross osteoporosis.

\section{Surgical Procedure}

By standard posterior midline incision .The affected site was exposed. Awl was put under image intensifier for the exact portal of entry. The pedicle probe and the depth gauge were used to know the appropriate size of the pedicle screws.
Prior to rod placement, the alignment tool was also used. The rod was cut to a length. Contoured to conform to the sagittal contour of the spine. Autogenous Cortico Cancellous born graft was placed either before or after the placement of the rod. Secure tightening of each set screw was performed with the screw driver in conjunction with the rod pusher. Postoperative antibiotics were used for three days. The patient was allowed to ambulate under supervision on the first postoperative day with taylor brace. In paraplegics and in patients with partial recovery, parallel bar gait training was started after 6 weeks with the help of a physiotherapist. Check radiographs were taken to confirm stability, reduction, vertebral height and change in kyphotic angle. Patients were followed up for a period of one year. The results were analyzed on the basis of:

1) Neurological recovery as per FRANKEL GRADING (ASIA impairment scale),

2) Spine stability (Kyphotic angle, Vertebral body height, Status of fusion) and

3) Complications

4) (a)General- Bed Sores, RTI, UTI, Deep venous thrombosis, Joint contractures.

b)Surgery related- Screw loosening, Screw breakage, Rod breakage, Wound infection and Improper placement of screws)

Fig-I

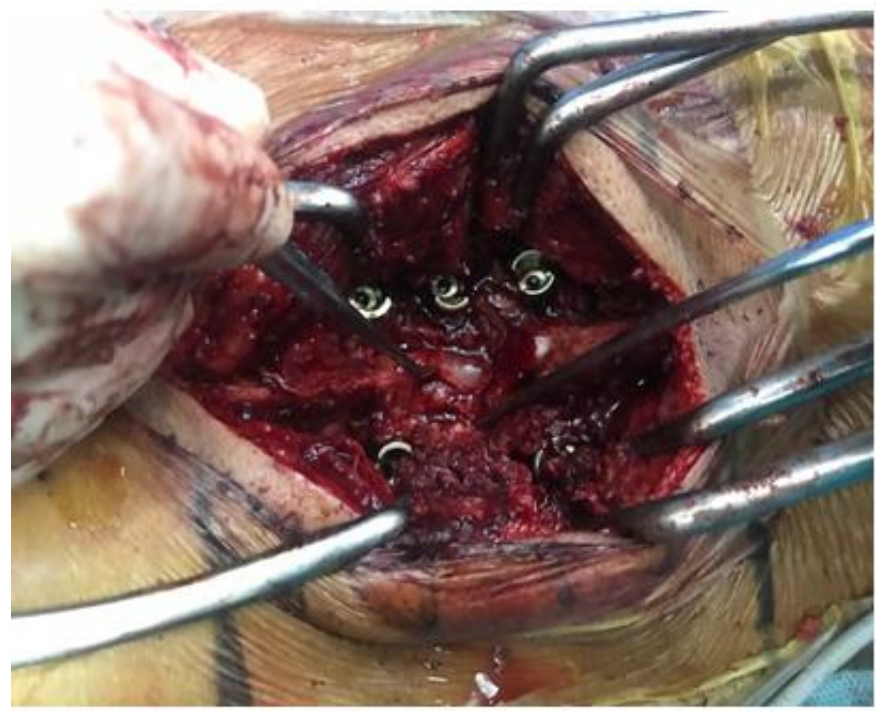


Table-I Age Distribution

\begin{tabular}{|l|c|c|}
\hline Age & No. of Patients & Percentage of Patients \\
\hline $21-30$ & 13 & 65 \\
\hline $31-40$ & 4 & 20 \\
\hline $41-50$ & 3 & 15 \\
\hline
\end{tabular}

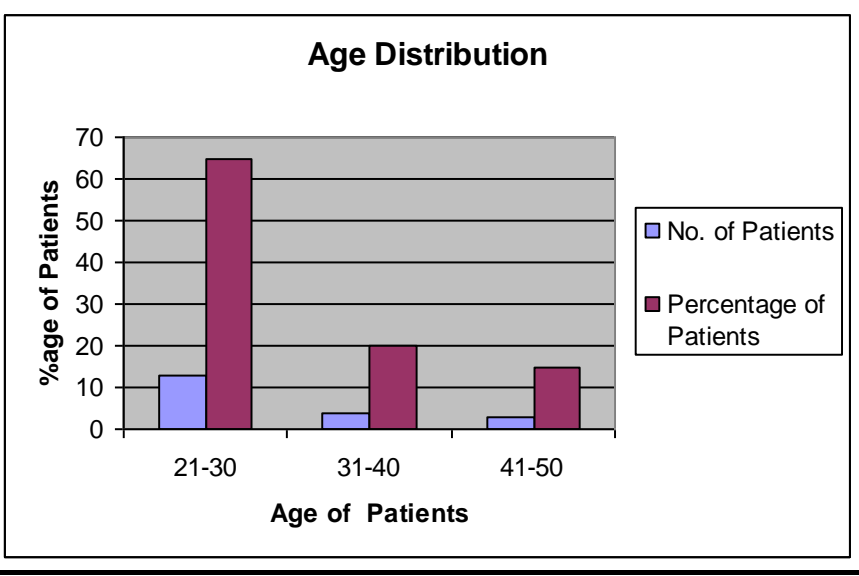

Table-II Sex Distribution

\begin{tabular}{|l|c|c|}
\hline Sex & No. of Cases & \%age of Cases \\
\hline Male & 19 & 95 \\
\hline Female & 1 & 5 \\
\hline
\end{tabular}

Table-III Duration between Injury and Admission

\begin{tabular}{|l|c|c|}
\hline Duration & No. of Cases & \%age of Cases \\
\hline$<48$ hours & 9 & 45 \\
\hline$>48$ hours & 11 & 55 \\
\hline
\end{tabular}

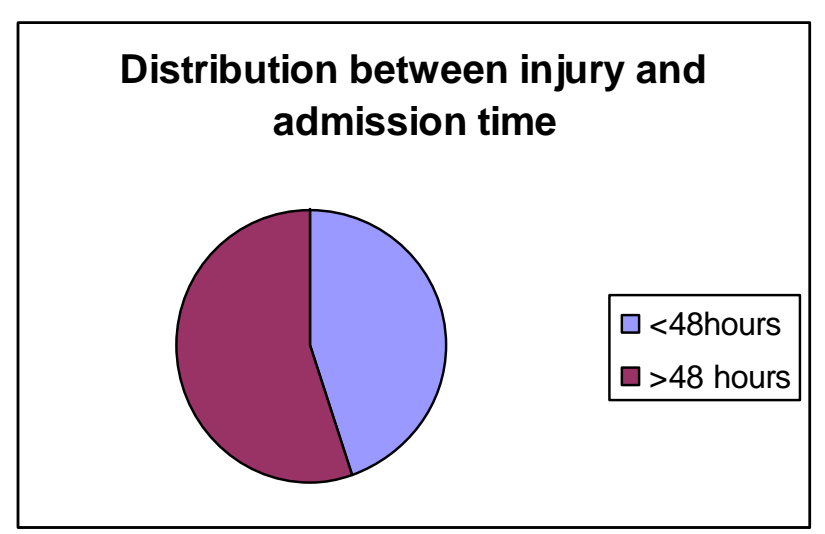

Table-IV Mode of Trauma

\begin{tabular}{|l|c|c|}
\hline Mode of Trauma & No. of Patients & \%age of Patients \\
\hline Fall from height & 12 & 60 \\
\hline RTA & 4 & 20 \\
\hline $\begin{array}{l}\text { Fall of heavy } \\
\text { object over back }\end{array}$ & 4 & 20 \\
\hline
\end{tabular}

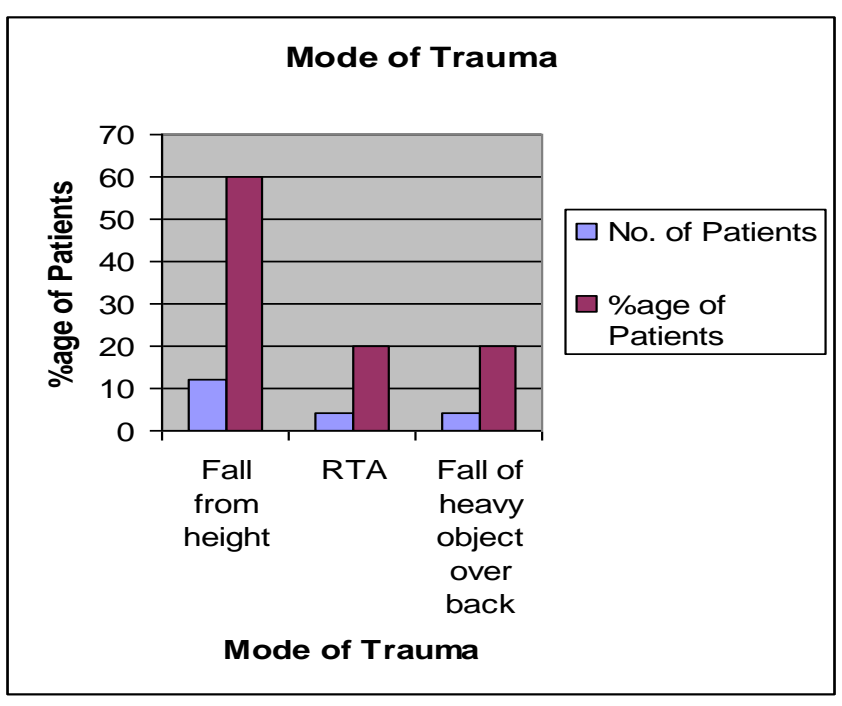

Table-V Type of Injury

\begin{tabular}{|l|c|c|}
\hline Type & $\begin{array}{c}\text { No. of } \\
\text { Cases }\end{array}$ & $\begin{array}{c}\text { \%age of } \\
\text { Cases }\end{array}$ \\
\hline Wedge Compression Fracture & 6 & 30 \\
\hline Burst Compression Fracture & 10 & 50 \\
\hline Rotational Fracture Dislocation & 4 & 20 \\
\hline
\end{tabular}

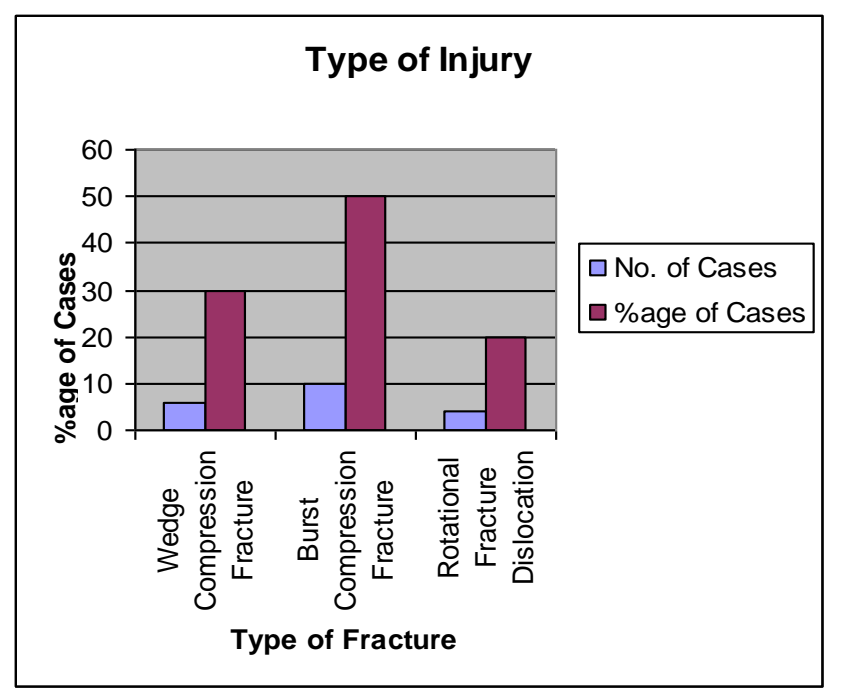

Table-VI Level of Injury

\begin{tabular}{|l|c|c|}
\hline Vertebra Involved & No. of Cases & \%age of Cases \\
\hline D1 23 & 0 & 0 \\
\hline D4 56 & 0 & 0 \\
\hline D7 & 0 & 0 \\
\hline D8 & 1 & 5 \\
\hline D9 & 0 & 0 \\
\hline D10 & 0 & 0 \\
\hline D11 & 1 & 5 \\
\hline D12 & 3 & 15 \\
\hline L1 & 10 & 50 \\
\hline L2 & 4 & 20 \\
\hline L3 & 1 & 5 \\
\hline L4 & 0 & 0 \\
\hline L5 & 0 & 0 \\
\hline
\end{tabular}


Table-VII Associated Injury

\begin{tabular}{|l|c|c|}
\hline Type of Injury & $\begin{array}{c}\text { No. of } \\
\text { Cases }\end{array}$ & $\begin{array}{c}\text { \%age of } \\
\text { Cases }\end{array}$ \\
\hline Fracture of Right Calcaneum & 1 & 5 \\
\hline Fracture of Tibia \& Fibula & 1 & 5 \\
\hline $\begin{array}{l}\text { Fracture of Right Superior \& } \\
\text { Inferior Pubic Ramii }\end{array}$ & 1 & 5 \\
\hline
\end{tabular}

Table-VIII Neurological Status on Admission

\begin{tabular}{|l|c|c|}
\hline $\begin{array}{l}\text { FRANKNEL GRADE } \\
\text { (ASIA Scale) }\end{array}$ & $\begin{array}{c}\text { No. of } \\
\text { Patients }\end{array}$ & $\begin{array}{c}\text { \%age of } \\
\text { Patients }\end{array}$ \\
\hline A & 11 & 55 \\
\hline B & 4 & 20 \\
\hline C & 5 & 25 \\
\hline D & 0 & 0 \\
\hline E & 0 & 0 \\
\hline
\end{tabular}

Table-IX Final Neurological Status

\begin{tabular}{|l|c|c|}
\hline $\begin{array}{l}\text { FRANKEL GRADE } \\
\text { (ASIA Scale) }\end{array}$ & $\begin{array}{c}\text { No. of } \\
\text { Patients }\end{array}$ & $\begin{array}{c}\text { \%age of } \\
\text { Patients }\end{array}$ \\
\hline A & 10 & 50 \\
\hline B & 0 & 0 \\
\hline C & 4 & 20 \\
\hline D & 5 & 25 \\
\hline E & 1 & 5 \\
\hline
\end{tabular}

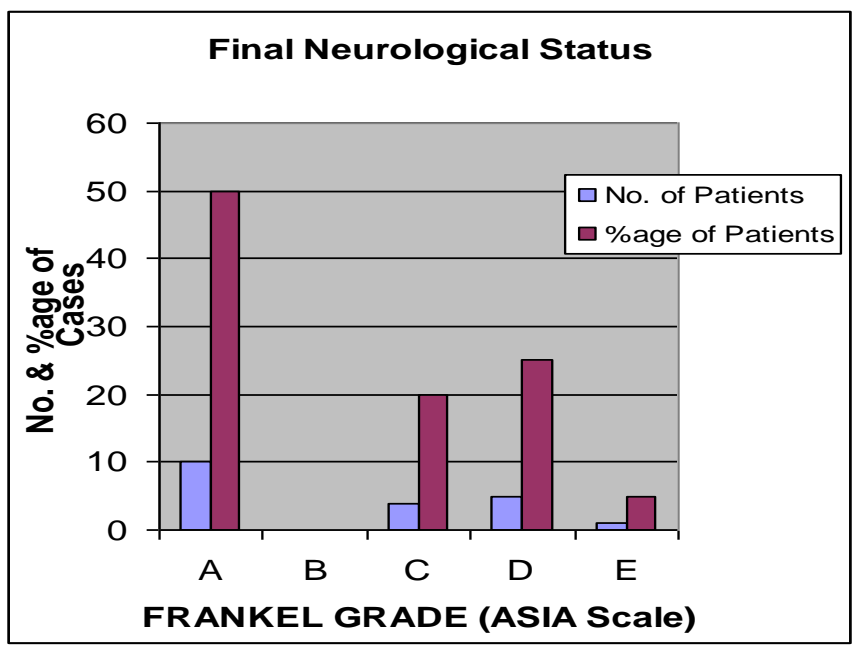

Table-X Vertebral Height

\begin{tabular}{|l|c|c|}
\hline Cases & $\begin{array}{c}\text { Vertebral } \\
\text { Height Range \% age }\end{array}$ & Average \\
\hline Pre Operative & $46.20-70.20$ & $61.60 \%$ \\
\hline Post Operative & $53.40-81.80$ & $71.56 \%$ \\
\hline
\end{tabular}

Table-XI Kyphotic Angle

\begin{tabular}{|l|c|c|}
\hline Cases & Range & Average \\
\hline Pre Operative & $10^{0}-45^{0}$ & $28.36^{0}$ \\
\hline Post Operative & $5^{0}-30^{0}$ & $12.15^{0}$ \\
\hline
\end{tabular}

Table-XIII General Complications

\begin{tabular}{|l|c|c|}
\hline Complications & $\begin{array}{c}\text { No. of } \\
\text { Cases }\end{array}$ & $\begin{array}{c}\text { \%age of } \\
\text { Cases }\end{array}$ \\
\hline Bed Sore & 2 & 10 \\
\hline Urinary Tract Infection & 1 & 5 \\
\hline $\begin{array}{l}\text { Upper Respiratory Tract } \\
\text { Infection }\end{array}$ & 1 & 5 \\
\hline Deep vein Thrombosis & 0 & 0 \\
\hline Joint Contractures & 0 & 0 \\
\hline
\end{tabular}

\section{General Complications}

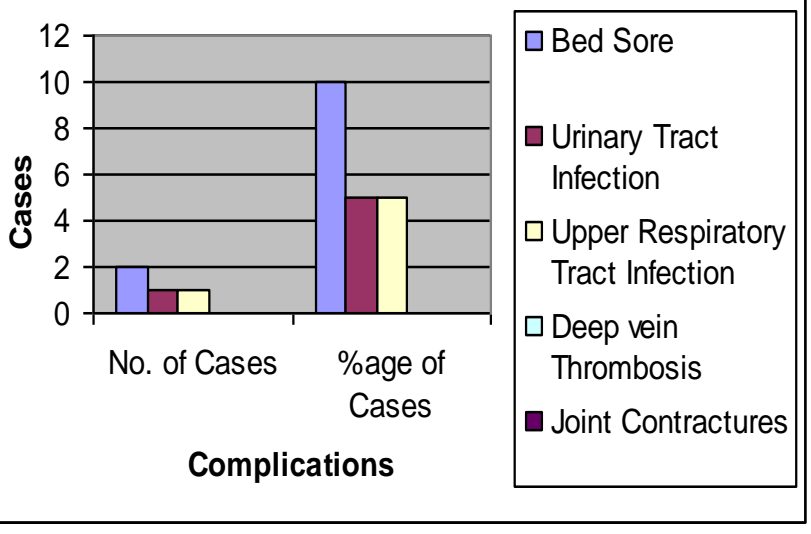

Table-XIV Complications related to surgery

\begin{tabular}{|l|c|c|}
\hline Complications & $\begin{array}{c}\text { No. of } \\
\text { Cases }\end{array}$ & $\begin{array}{c}\text { \%age of } \\
\text { Cases }\end{array}$ \\
\hline Screw Breakage & 0 & 0 \\
\hline Rod Slippage & 1 & 5 \\
\hline Superficial Wound Infection & 1 & 5 \\
\hline Osteomyelitis & 0 & 0 \\
\hline
\end{tabular}

\section{Complications related to surgery}
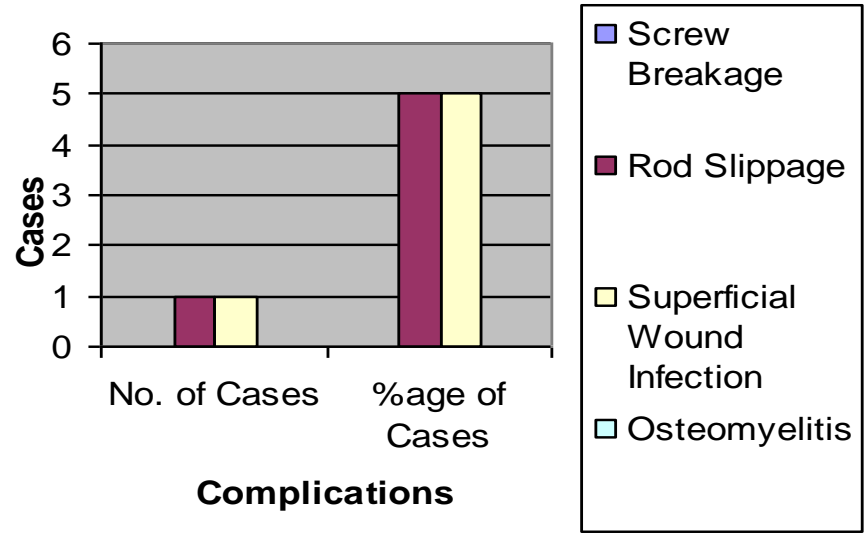

Table-XVI Status of Fusion

\begin{tabular}{|l|c|c|}
\hline Status of Fusion & No. of Cases & \% age of Cases \\
\hline Union & 18 & 90 \\
\hline Non-Union & 02 & 10 \\
\hline
\end{tabular}




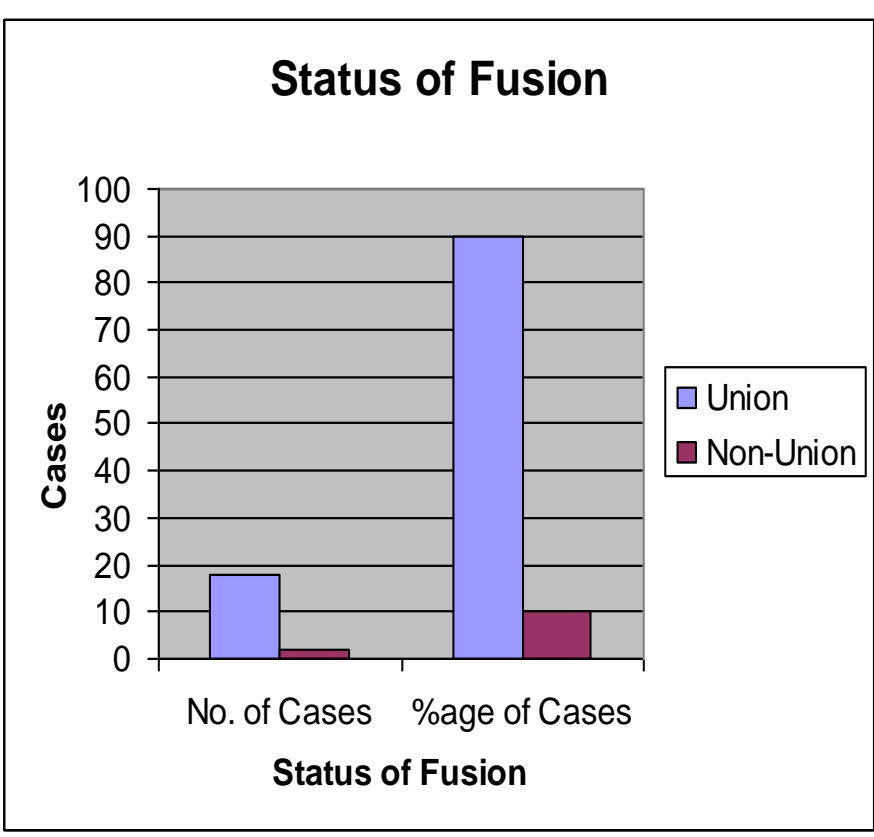

Fractures of thoracolumbar spine are very common. Most of them are unstable. Thus management of these fractures by conservative methods is difficult. They are also associated with neurological deficit which aggravates it further. Most authors agree on anterior decompression. Posterior spinal fixation has the advantage of being a less extensive approach with fewer postoperative complications without compromising on the quality of stabilization. The aim of this study was to assess the results of the operative management of post-traumatic thoracic and lumbar spine fractures with neurologic deficit.

\section{Discussion}

We studied 20 cases of thoracolumbar spine injuries with neurologic-deficit. They were treated by decompression and posterior spinal fixation by pedicle screws. $95 \%$ of them were males ${ }^{(6,7)} .65 \%$ of them were of the age group of 21-30 years with mean age of 29.7 years ${ }^{(6,7,18,21)}$. Both of these factors are indicators of active outdoor life and consequent increased risk of injury. The commonest mode of injury was fall from height $60 \%$ of patients $\left.{ }^{(5,6,7} 18\right)$. This correlates with the fact that burst compression was the commonest mechanism causing the fractures. The commonest level of vertebral involvement was thoracolumbar junction. L1 50\%, L2 $20 \%$ and D12 in $15 \%$ of the patients $^{(6,718,30,31)}$. The commonest type of fracture was Type-II (Burst compression type) in 50\% of the cases, Type-I (Wedge compression type) and Type-III (Rotational fracture- dislocation type) in $20 \%$ of the cases ${ }^{(13,14,19,21)}$. Only cases with neurological-deficit were included. $55 \%$ of the cases were with Grade A power, $25 \%$ cases with Grade $C$ power and $20 \%$ of cases were with Grade B power on admission ${ }^{(6,7,18,21)} .30 \%$ of the patients had useful recovery (Grade D \& E) and 50\% patients showed recovery by one or more grade by Frankel System of Grading ${ }^{(12,31)}$. None of the patients in this study had any neurological deterioration. All patients having incomplete neurological deficit showed some recovery. Preoperative degree of kyphotic deformity ranged from $10^{\circ}$ to $45^{\circ}$ with an average of $28.36^{\circ}$.

On follow up average degree of correction of kyphotic deformity was noted as $12.75^{\circ}$ with range of $5^{0}-30^{(6,7)}$. The complications related to surgery were one patient with rod slippage (5\%), one patient with superficial wound infection $(5 \%)$. General complication like bedsores were noted in 2 patients $(10 \%)$ and one with urinary tract infection $(5 \%) \&$ upper respiratory tract infection $(5 \%)$.

\section{Conclusion}

It is widely accepted that the spinal deformity should be reduced as early as possible. A careful decompression is just an extension of the accepted theory of reduction providing maximum available space for the neurological elements. In this study we have found pedicle screw fixation fulfills all the aims of surgical treatment of fractures and fracture dislocation of thoracolumbar spine with neurologic involvement. The stability provided prevents further neural damage. During our study of 20 patients it was observed that posterior stabilization with pedicle screw was effective. It also showed a fair improvement in the neurological status. Neurological recovery was good in patients with incomplete cord Injury. Early mobilization and ambulation is one of the major advantages of this procedure which shortens 
the rehabilitation. The results in our short series of 20 cases have been encouraging. But there is need for more cases and longer follow-up to come to categorical conclusion.

\section{References}

1. Akbarina BA (1993) Surgical treatment of upper Thoracic fractures using CotrrelDobusset Instrumentation. Spine: State of the Art Reviews. 7(2): 269-276.

2. Arvind Jayaswal, MS(Orth); Bijjawara Mahesh and Abrar Ahmed. Spinal Injuries an overview. Orthopaedics Today, JanMarch 2003 Vol. IV No. 7

3. Bartha AG, Robert AC, Klose KJ, and Torre J. Acute spinal cord injury, current concept. Clin Ortho 1981; 154:125-35.

4. Bastian L, Knop C, Lange U, Blauth M. Transpedicular implantation of screws in thoracolumbar spine. Resultsof a survey of methods, frequency and complications. Orthopade.1999; 28(8):693-702234-9.

5. Burke DC, Murray DD. The management of Thoracic and thoracolumbar injuries of spine with neurological involvement. Bone and Joint Surg., 1976; 58B:

6. Chadha M, Bahadur R (1998)Steffee variable screw placement in the management of unstable thoracolumbar fractures. Injury. 1998 Dec; 29(10):73742.

7. Chavda DV, Brantigan JW. Technique of reduction of internal fixation of thoracolumbar fracture dislocation using pedicle screws .Orthop Rev. 1994; Suppl.

8. Dickman CA, Yahiro MA, Lu HT, MelkersonMN (1994) Surgical treatment alternatives for fixation of unstable fractures of thoracic and lumbar spine. A meta-analysis. Spine 19: 2266S- 2273S

9. Dickson JH, Harrington PR, Erwin WD. Results of reduction and stabilization of severely fractured thoracic and lumbar spine. J. Bone Joint Surg AM 1978 Sep 1978; 60(6):799-805.
10. Flesch JR, Leider LL, Ericson DL, Chou SN, Bradford DS. Harrington instrumentation and spine fusion for unstable fractures and fracture-dislocations of the thoracic and lumbar spine. $\mathrm{J}$ Bone Joint Surg Am. 1977; 59(2): 143-53.

11. Jacobs R.R., Asher M.A., Snider R. K. (1980). Thoracolumbar spinal injuries: A comparative study of recumbent and operative treatment in 100 patients. Spine 1980;5:463-77.

12. Kaya RA, Aydin Y. Modified transpedicular approach for the surgical treatment of severe thoracolumbar and lumbar burst fractures. Spine J. 2004; 4(2): 208-217.

13. Knop C, Bastian L, Lange U, Oeser M, Zdichavsky M, Blauth M (2002) Complications in surgical treatment of thoracolumbar injuries. Eur Spine J Springer link DOI 10.1007/s00586-0010382-6.

14. Knop C, Fabian HF, Bastian L Blauth M (2001) Late results of thoracolumbar fractures after posterior instrumentation and transpedicular Bone Grafting. Spine 26:88-99

15. Odgers CJ $4^{\text {th }}$, Vaccaro AR, Pollack ME, Colter JM. Accuracy of pedicle screw placement with lateral plain radiography. J Spinal Disord. 1996; 9(4): 334-8.

16. Olerud S, Karlstrom G, Sjostrom L (1998)Transpedicular fixation of thoracolumbar vertebral fractures. ClinOrthop 227:44-51.

17. Odgers CJ $4^{\text {th }}$, Vaccaro AR, Pollack ME, Colter JM. Accuracy of pedicle screw placement with lateral plain radiography. J Spinal Disord. 1996; 9(4): 334-8..

18. Razak M, Mahmud MM, Hyzan MY, Omar A. Short segment posterior instrumentation and fusion of unstable thoracolumbar burst fractures- a review of 26 cases. Med J Malaysia. 2000; 55 Suppl. C: 9-13. 
19. Roberts JB, Curtiss PH. Stability of thoracic and lumbar spine in traumatic paraplegia following fractures or fracture dislocation. Jour. Bone \& Joint Surg. 1970; 52A:1115.

20. Roy-Camille R, Saillant G (1984) Les traumatisms du rachis sans complications neurologique. IntOrthop 8:155-162.

21. Sangwan SS, Chand S, ChadhaNS. Treatment of fractures and fracture dislocation of dorsolumbar spine by Harrington Instrumentation and Luque wiring. Ind. Journal of Orthop. 25, 1991; No. 2: 93-95.

22. Schmucki D, Gebhard F, Grutzner PA, Hufner T, Langlotz F, Zheng G. Computer aided reduction and imaging. Injury. 2004; 35 Suppl. 1:S-A96-104.

23. Soreff J, Axdorph G, Bylund P, Olerud S. Treatment of patients with unstable fracture of thoracic and lumbar spine- a follow up of surgical and conservative treatment. ActaOrthop. Scand., 1982: 53: 369.

24. Terregino CA, Ross SE, Lipinski MF, et. al. Selective indications for thoracic and. lumbar radiography in blunt trauma. Ann Emerg Med. 1995; 26:126-9.

25. Vaccaro AR, Rizzolo SJ, Balderston RA et al. Placement of pedicle screws in the thoracic spine. Part II: An anatomical and radiographic assessment. J Bone \& Joint Surg. Am. 1995 Aug; 77(8) 1200-6.

26. Weinstein JN, Spratt KF, Spengler D, Brick CR. Spinal pedicle fixation: reliability and validity of roentgenogrambased assessment and surgical factors on successful screw placement. Spine. 1988; 13(9): 1012-8.

27. Weiss $M$ and Bentokowiski $Z$. Biomechanical study in dynamic spondylodesis of the spine. Clin Ortho, 1974; 103: 199-203.

28. White RR, Newberg A, Seligson D. Computerized tomographic assessment of the traumatized dorsolumbar spine before and after Harrington Instrumentation. ClinOrthop., 146: 150, 1980.

29. Wilson PD and Straub LR. Lumbosacral fusion with metallic plate fixation, instructional course lectures. Amer. Acad. Of Ortho. Surg., 9:53-57.

30. Young MH. Long term consequences of stable fractures of the thoracic and lumbar vertebral bodies. Jour. Bone \& Joint Surg., 1973; 55B 295.

31. Yue JJ, Sossan A, Selgrath C et al. The treatment of unstable thoracic spine fractures with transpedicular screw instrumentation- a 3 year consecutive series. Spine. 2002; 27(24): 2782-7.

32. Zheng ZG, Cheng MH, Dong TH. Unstable fracture of thoracolumbar spine treated with pedicle screw plating. A report of 90 cases. Chin Med J (Engl). 1994; 107 (4): 281-5.

33. Zou D, Ma H, Hai Y. Significance of surgical treatment of bursting fracture with CT estimation analysis of the anatomy of pedicle of vertebral arch Zhonghua. WaiKeZaZhi. 1997; 35(6): 344-7.

34. Robert Bucholz W, James Heckman D. Rockwood and Greens Fractures in adults; Lippincott Willams and Willkins; 5th edition. 2001; 2:1293-1466. 2.

35. Guttman L. Spinal cord injuries comprehensive management and research; Oxford: Blackwell Scientific publications. 1976, 137-176. 3. 36.Watson Jones R. Fractures and Joint Injuries; Ed. J.B. Wilson, Edinburgh: Churchill Livingstone: 1982, 789792. 